\title{
Associated laparoscopic-assisted gastropexy and ovariohisterectomy in a Great Dane bitch
}

\author{
Associação de gastropexia e ovariohisterectomia vídeo assistida em cadela Dogue Alemão
}

\author{
Saulo Tadeu Lemos Pinto Filho ${ }^{I}$ Fabíola Dalmolin ${ }^{I}$ Marília Teresa de Oliveira ${ }^{I}$ \\ Fernando Wiecheteck de Souza ${ }^{I}$ Arícia Gomes Sprada' ${ }^{I}$ Matheus Pippi da Rosa \\ João Pedro Scussel Feranti ${ }^{I}$ Mauricio Veloso Brun ${ }^{\text {III }}$
}

- NOTE -

\section{ABSTRACT}

Gastropexy techniques are performed aiming to adhere permanently the stomach to the abdomen, being this one of the most common indications for prevention and treatment of gastric dilatation-volvulus (GDV). The only accepted method for the prevention of $G D V$ is the prophylactic gastropexy, and the laparoscopic-assisted procedure is quick and easy to perform. It is aimed to report the association of laparoscopic-assisted prophylactic gastropexyand elective ovariohysterectomy (OVH) in a two years old Great dane bitch using the two-portals access, when it was observed rapid and complete recovery. It is concluded that the two portals laparoscopic-assisted prophylactic gastropexy is feasible and safe in dogs, when combined with elective OVH. It makes the technique a suitable option for prevention of GDV in predisposed breeds.

Key words: stomach, laparoscopic-surgery, dog.

\section{RESUMO}

As técnicas de gastropexia são realizadas objetivando aderir o estômago permanentemente ao abdômen, sendo comumente indicadas na prevenção e tratamento da dilatação vólvulo-gástrico (DVG). O único método aceito para a prevenção da GDV é a gastropexia profilática, a qual pode ser realizada pelo acesso videoassistido de forma rápida e fácil. Objetiva-se relatar a associação de gastropexia profilática videoassistida e ovariohisterectomia (OVH) eletiva em uma cadela Dogue alemão, com dois anos de idade, pela técnica de dois portais, na qual se observou rápida e completa recuperação da paciente. Concluise que a gastropexiavideoassistida profilática associada à $\mathrm{OVH}$ videoassistida com dois portais, durante única intervenção, é factível e segura para cães, tornando-se uma opção adequada na prevenção da DVG em raças predispostas.

Palavras-chave: estômago, videocirurgia, cão.

\section{INTRODUCTION}

Acute dilatation of the stomach, associated with torsion, is a harmful event that occurs more often in large and giant-breed dogs such as Akita, Collie, Irish Setter, Rottweiler, Standard Poodle, Weimaraner, Great Dane, Irish Wolfhound, Newfoundland and Saint Bernard. The incidence of gastric dilatationvolvulus (GDV), in these breeds, reaches 6\% and represents $16 \%$ of all causes of death (GLICKMAN, et al., 2000). This acute condition requires emergency treatment that may or may not be associated with surgical therapy as an attempt to increase the chances of success and the maintenance of the patient's life. A prompt identification of the problem, the choice of an appropriated therapy and an early stabilization of the patient are the key factors of a successful treatment (SILVA et al., 2012).The gastric repositioning combined with gastropexy reduces the risk of a recurrence to less than $5 \%$, whereas the procedure of gastric repositioning only is associated with up to $80 \%$ of recurrence (WARD et al., 2003).

Gastropexy techniques are performed aiming the permanent adherence of the stomach to the abdominal wall, and the most common indications for its use are gastric dilatation-volvulus (GDV) and hiatal hernia (HEDLUND \& FOSSUM, 2007). In cases of GDV, the adhesion is made between the pyloric antrum and the right side of the abdominal

\footnotetext{
IPrograma de Pós-graduação em Medicina Veterinária, Universidade Federal de Santa Maria (UFSM), Santa Maria, RS, Brasil. "Curso de Medicina Veterinária, UFSM, Santa Maria, RS, Brasil.

IIIDepartamento de Clínica de Pequenos Animais, UFSM, Av. Roraima, 1000, 97105-900, Santa Maria, RS, Brasil. E-mail: mauriciovelosobrun@hotmail.com. Corresponding author. 
wall (RASMUSSEN, 2007).This adhesion may be achieved by different techniques including the incisional, the belt-loop, the circumcostal and the tube gastropexy. All these procedures are considered of fast execution and effective to create a resistant attachment (SILVA et al., 2012).

The risk of death due to GDV was estimated using published data regarding the longevity and incidence of GDV in five canine breeds (Great Dane, Irish Setter, Rotteweiler, Standard Poodle and Weimaraner). The results ranged from 3.9\% in Rottweiler to $36.7 \%$ in Great Dane. The need to prevent GDV in the breeds studied also was verified; the authors concluded that prophylactic gastropexy decreased the mortality rate in all of them (2.2 times in Rottweiler and 29.6 times in Great Danes). Furthermore, the cost of prophylactic gastropexy was considerably lower than the cost of the GDV treatment ranging from 20 (Rottweiler) to 435 dollars (Great Dane), whereas the treatment of GDV was around 1500 dollars. However, prophylactic gastropexy raises ethical issues that must be considered by veterinarians and owners (WARD et al., 2003).

The only method accepted to prevent GDV is the prophylactic gastropexy (RAWLINGS, 2007; MATHON et al., 2009; LOPES, 2012). However, a relatively small number of susceptible dogs will be submitted to this prophylactic surgery probably because it is an invasive procedure, specially, when performed by traditional open laparotomy (RAWLINGS, 2007).The major advantages of the laparoscopic-assisted gastropexy are that it requires only a minimal surgical approach using two small incisions and also promotes strong adhesion (RAWLINGS, 2007; RODRIGUEZ et al., 2007).

LOPES (2012) applied the laparoscopic technique to perform prophylactic gastropexy in six dogs, potentially predisposed to develop GDV, assessing the level of complexity of the technique, its duration, size of the adhesion area and the possible intraoperative complications. The researcher concluded that the laparoscopic approach is feasible, rapid in implementation and provides a faster and less painful recovery of the patients. Besides that, according to RIVIER et al. (2011), the opportunity to perform the ovariohysterectomy or ovariectomy and the gastropexy simultaneously may be advantageous to the patient, especially when laparoscopic techniques are used due to the decrease of the morbidity. The purpose of this article was to report a case of combined laparoscopic ovariohysterectomy $(\mathrm{OVH})$ and laparoscopic-assisted prophylactic gastropexy in a Great Dane bitch.
A two-year-old intact female of Great Dane was admitted in the Hospital Veterinário Universitário of UFSM for surgical neutering and elective gastropexy. The patient's owner opted for laparoscopic surgery. By the clinical evaluation, hemogram and biochemical tests the patient was considered healthy and it was referred for surgery. After fasting of 12 hours, the patient was premedicated with tramadol hydrochloride $\left(4 \mathrm{mgkg}^{-1}\right)$ and acepromazine maleate $\left(0,05 \mathrm{mgk}^{-1}\right)$ administered intra-muscularly (IM), followed by venous cannulation with catheter $20 \mathrm{G}$ and ringer lactate fluid was administered intravenous (IV) at $10 \mathrm{mlkg}^{-1} \mathrm{~h}^{-1}$ during the procedure. The patient was induced with diazepam $\left(0.5 \mathrm{mgkg}^{-1}\right)$ and propofol $\left(2 \mathrm{mgkg}^{-1}\right)$, both IV. The dog was intubated and anesthesia was maintained with inhalation of isoflurane in $100 \%$ oxygen. For pain control epidural anesthesia was performed which contained the association of lidocaine hydrochloride $2 \%$ without epinephrine $\left(2 \mathrm{mgkg}^{-1}\right)$, bupivacaine also $2 \%$ without epinephrine $\left(2 \mathrm{mgkg}^{-1}\right)$ and morphine sulfate $\left(0.1 \mathrm{mgkg}^{-1}\right)$. Cephalothin sodium $\left(30 \mathrm{mgkg}^{-1}\right)$ was used as an antibiotic prophylaxis, IV 30 minutes before the beginning of the surgery.

After the patient was placed in dorsal recumbency and the skin was prepared for surgery. An incision of $1.5 \mathrm{~cm}$ was made at the umbilicus involving skin and subcutaneous tissue. Then, a $10 \mathrm{~mm}$ cannula was introduced into the cavity and it was fixed to the skin with suture.Following abdominal insufflation with carbon dioxide to an intra-abdominal pressure of $12 \mathrm{mmHg}$, another $10 \mathrm{~mm}$ cannula was inserted into the ventral midline cranial to the urinary bladder.

After placing the two portals, the patient was placed in right lateral recumbency to improve access to the ovary by the displacement of the viscera. The left ovary was grasped with a forceps and the proper and suspensory ligaments were cuted, allowing the temporary attachment of the ovary to the abdominal wall. To perform the attachment, the ovary was pulled towards the lateral wall and it was fixed with transmural suture applied externally under visualization. Hemostasis was performed making use of extracorporeal ligation with nylon size 0 and endoloop knot was applied, followed by the section of the mesometrium and mesovary (Figure 1A and B). The ovary was then released and the patient was positioned in contralateral recumbency repeating the previous maneuvers also in the right ovary.

Both ovaries were gently pulled through the second access with extra cavitary exposure of these organs and the uterine horns. In the cervix region three clamps were placed and two transfixing ligatures 

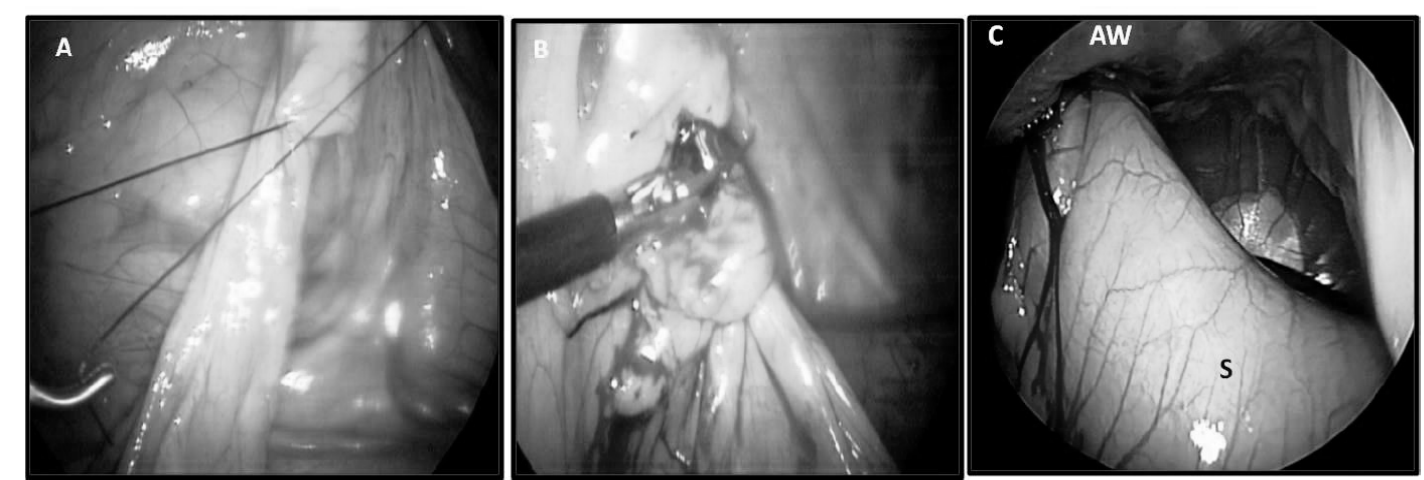

Figure 1-Elective OVH procedure via two portals in a 2-year-old Great Dane bitch. Note the ligature of the left ovarian vessels (A), followed by the incision of these vessels and part of the mesometrium and mesovary (B), laparoscopic image of the stomach's fixation (S) the right abdominal wall (AW) of a 2-year-old great dane bitch underwent to video-assisted gastropexy associated to OVH via two portals (C).

were applied with 0 polyglactin 910.The caudal abdominal incision was sutered with 0 polyglycolic acid with Wolff knot. The skin was closed with 2-0 mononylon in simple interrupted pattern.

After completing $\mathrm{OVH}$, a third $10 \mathrm{~mm}$ cannula was introduced in the right hypogastric region and the telescope was remained in the umbilical cannula. Then the stomach was located and apprehended with a Kelly forceps in order to exposure the organ through the third access, which had to be increased 2.0 centimetres aiming less injury to the tissue. Traction sutures of 2-0 mononylon were placed in the stomach, and a longitudinal incision was made in the serous and muscular layer of the pyloric region. The seromuscular layer was sutured to the right lateral abdominal wall with Sultan sutures of 2-0 polyglactin 910 (Figure 1C). The cannula sites, the subcutaneous tissues and the skin were closed routinely, as previously described by RAWLINGS (2007).

Postoperatively it was administered tramadol hydrochloride $\left(2.5 \mathrm{mgkg}^{-1}, \mathrm{SC}, \mathrm{BID}\right.$, for two days) and meloxicam $\left(0.2 \mathrm{mgkg}^{-1}, \mathrm{SC}\right.$, SID, for three days). The patient was discharged at the same day after its full anesthesia recovery. The surgical procedures lasted 126 minutes ( 74 minutes for $\mathrm{OVH}$ and 52 minutes for gastropexy) and there was no complication during and post-surgery. The skin's sutures were removed following 10 days and complete healing was observed.

GDV is a clinical-surgical syndrome of acute character which affects dogs of predisposing breeds and can lead to rapid death if not diagnosed and treated quickly. In this case the surgery team was contacted by the owner to perform OVH to avoid undesired pregnancy. On the occasion, the possibility of a laparocopic-assisted gastropexy was considered thereby decreasing the risk of GDV, since the patient was a Great Dane dog breed that is considered highly predisposed to develop the syndrome.

WARD et al. (2003) found in their studies that when prophylactic gastropexy was performed in Great Dane dogs, it resulted in 26 times less mortality rates when compared to animals that did not undergo to prophylactic procedure. LOPES (2012) also studied the gastropexy techniques in dogs. The results showed that the combination of elective surgery with prophylactic gastropexy can be advantageous to the patient as was observed in this case. A single anesthetic event and the minimally invasive technique seem to be the main advantages of this conduct.

Therefore, this case reports that such operations can be safely performed by a surgeon who possesses the equipment, instrumental and training in laparoscopic techniques. The technique is efficient, relatively quick and easy and cause minimal stress to the patient (HARDIE, et al., 1996). This operation clearly leads to a firm and permanent attachment of the stomach to the abdominal wall with minimal lesion and manipulation when compared to the similar conventional surgery.

RAWLINGS (2007) recommends two incisions: one in the abdominal midline just caudal to the umbilicus and another on the right lateral wall of the abdomen just behind the last rib. In this present case, there was a slight variation of the technique due to the $\mathrm{OVH}$ procedure. For this reason it was necessary a second incision in the midline caudal to the pre-pubic region to expose the uterus. RODRIGUEZ et al. (2007) studied two laparoscopic gastropexy techniques in dogs and also concluded

Ciência Rural, v.45, n.2, fev, 2015. 
that Rawlings' technique is faster when compared to the technique that uses two portals on the right side of the animal. Besides that, it proved to be easy to perform and produce a minimal wound of $4 \mathrm{~cm}$. In this report, the three incisions made to introduce the portals were approximately $1.5 \mathrm{~cm}$, but one of them had to be expanded to tree centimetres in order to cause less tissue damage. The dog recovered satisfactorily demonstrating appetite after 6 hours from the end of the procedure. Eleven months after surgery, the patient was in good health presenting almost imperceptible scars.

It was concluded that laparoscopicassisted prophylactic gastropexy is feasible and safe for dogs when performed along with elective $\mathrm{OVH}$ with two portals, being a suitable option to prevent GDV in predisposed breeds.

\section{ETHICS COMMITTEE AND BIOSAFETY}

The report met with an animal runs in the routine of the University Veterinary Hospital - UFSM - and was not part of any project, with only one case report.

\section{REFERENCES}

GLICKMAN, L.T. et al. Non-dietetary risk factors for gastric dilatation-volvulus in large and giant breed dogs. J Am Vet Med Assoc, v.217, p.1492-1499, 2000. Available from: <http://www. researchgate.net/publication/12199444>. Accessed: Jan.14, 2014. doi: 10.2460/javma.2000.217.1492.

HARDIE, R.J. et al. Biomechanical and histological evaluation of a laparoscopic staples gastropexy technique in dogs. Vet Surg, v.25, p.127-133, 1996. Available from: <http://www.ncbi.nlm.nih.gov/ pubmed/8928390>. Accessed: Jan.14, 2014. doi: 10.1111/j.1532950X.1996.tb01388.x
HEDLUND, C.S.; FOSSUM, T.W. Surgery of the digestive system. In: FOSSUM, T.W. Small animal surgery. 3.ed. St. Louis: Elsevier, 2007. Cap.19, p.339-530.

LOPES, A.F. Gastropexia profilática assistida por laparoscopia. 2012. 101f. Dissertação (Mestrado em Medicina Veterinária) Faculdade de Medicina Veterinária, Universidade Técnica de Lisboa.

MATHON, D.H. et al. A laparoscopic-sutured gastropexy technique in dogs: mechanical and functional evaluation. Vet Surg, v.38, p.967-974, 2009. Available from: <http://www.ncbi.nlm.nih.gov/ pubmed/20017855>. Accessed: Jan.15, 2014. doi:10.1111/j.1532950X.2009.00592.x.

RASMUSSEN, L. Estômago. In: SLATTER, D. Manual de cirurgia de pequenos animais. 3.ed. São Paulo: Manole, 2007. Cap.40, p.592-644.

RAWLINGS, C.A. Gastropexia assistida por laparoscopia. In: SLATTER, D. Manual de cirurgia de pequenos animais. 3.ed. São Paulo: Manole, 2007. Cap.40, p.592-644.

RIVIER, P. et al. Combined laparoscopic ovariectomy and laparoscopic-assisted gastropexy in dogs susceptible to gastric dilatation-volvulus. Can Vet J, n.52, p.62-66, 2011. Available from: $<$ http://www.ncbi.nlm.nih.gov/pmc/articles/PMC3003578/>. Accessed: Jan.15, 2014

RODRIGUEZ, C.A. et al. Gastropexia profiláctica en perros por medio de endocirugía. In: CONGRESO NACIONAL AVEPA, 42, 2007, Barcelona. Comunicaciones y Casos clínicos. Barcelona: AVEPA, 2007, p.270.

SILVA, S.S.R. et al. Síndrome da dilatação volvo gástrica em cães. Ciência Rural, v.42, n.1, p.122-130, 2012. Available from: $<$ http:// www.scielo.br/pdf/cr/v42n1/a1812cr5763.pdf $>$. Accessed: Jan. 13, 2014. doi: 10.1590/S0103-84782012000100020.

WARD, M.P. et al. Benefits of prophylactic gastropexy for dogs at risk of gastric dilatation-volvulus. Preventive Veterinary Medicine, v.60, p.319-329, 2003. Available from: <http://www. sciencedirect.com/science/article/pii/S0167587703001429> Accessed: Jan. 14, 2014. doi: 10.1016/S0167-5877(03)00142-9. 